\title{
Edukace žáků se speciálními vzdělávacími potřebami v přírodním prostředí
}

\author{
Nikola Adelaida Řandováa ${ }^{a}$ Alena Thorovská ${ }^{b}$ \\ a Ústav výzkumu a rozvoje vzdělávání, Pedagogická fakulta, Univerzita Karlova \\ ${ }^{\mathrm{b}}$ Katedra pedagogiky, Pedagogická fakulta, Univerzita Karlova
}

Redakci zasláno 21. 12. 2020 / upravená verze obdržena 23. 4. 2021 /

/ k uveřejnění přijato 25. 4. 2021

\begin{abstract}
Abstrakt: Problematika výchovy a vzdělávání žáků v přírodním prostředí patří $\mathrm{k}$ aktuálním tématům. Př́roda představuje přirozené prostředí, ve kterém jsme se vyvíjeli miliony let, a pobyt v př́rodním prostředí je tak naší evoluční potřebou. Kontakt s př́irodou však v současném světě, který je orientován spíše na technologie, velmi rychle mizí. Řada výzkumů odhaluje, že lidé tráví venku čím dál méně času. V souvislosti s tím se objevují také nové termíny jako „porucha z deficitu př́rody“, kterou ve své publikaci Last Child in the Woods použil Richard Louv (Daniš, 2016). Na potřebu většího kontaktu s přírodou tak reagují různé vzdělávací a výchovné strategie a další iniciativy, kterým není lhostejné, jakým směrem se bude utvářet vztah dětí k přírodě a jak bude pobyt venku ovlivňovat jejich zdraví. V současné epidemiologické situaci může být vzdělávání žáků v přírodním prostř̌edí velmi žádoucí, zejména u žáků, kteří mají potíže s dodržováním nezbytných hygienických opatření. Význam pobytu venku je v obecné rovině ověřen celou řadou výzkumů, ale vyvstávají otázky, je-li pobyt venku př́nosem pro všechny děti, jak na pobyt venku reagují žáci se speciálními vzdělávacími potřebami apod. Předložená studie je rozdělena na dvě relativně samostatné části; první je zaměřena na vzdělávání žáků se speciálními potřebami v prostředí školní zahrady a druhá na vzdělávání žákủ s poruchami chování v lesním prostředí. Studie přináší několik poznatků, které se mohou stát předmětem dalšího zkoumání a diskuzí. Jde například o zjištění téměř úplné absence negativních reakcí žáků na pobyt v zahradě (za každého počasí). Pozoruhodné jsou též zaznamenané názory některých pedagogických pracovníků na problematickou komplementaritu konceptu inkluze a vzdělávání v lesním prostředí.
\end{abstract}

Klíčová slova: edukace, žáci se speciálními vzdělávacími potřebami, prŕíroda, školní zahrada, porucha chování

Stále častěji se ukazuje, jak je pobyt venku pro děti důležitý, proto jsme se ve své studii na tuto problematiku zaměřily. V první části př́spěvku se věnujeme vzdělávání na školní zahradě na speciální škole, která je určena pro žáky se středně těžkým a těžkým mentálním postižením, souběžným postižením více vadami a autismem. Tito žáci vyžadují speciálněpedagogický přístup https://doi.org/10.5817/PedOr2021-2-201 
a systematickou podporu ve vzdělávacím procesu. Vybraná škola je adekvátně vybavena, personálně zabezpečena a disponuje také školní zahradou, která má nejen doplňovat vzdělávání, ale má také být místem odpočinku a relaxace. Hledali jsme odpovědi na následující otázky. Jak může školní zahrada pomáhat v naplňování specifických potřeb žáků a rozvíjet jejich kompetence? Jaký je postoj žáků a učitelů k výuce na školní zahradě? Cílem první části je popsat výuku na školní zahradě na jedné konkrétní škole a postoje tamních pedagogů $\mathrm{k}$ výuce $\mathrm{v}$ přírodním prostředí. Druhá část příspěvku je zaměřena na žáky s poruchou chování a jejich vzdělávání v lesním prostředím. Cílem je takové vzdělávání nejen popsat, ale také přinést názory pedagogů na takovou formu vzdělávání. Zjištění obou studií mohou ukázat možnosti, úskalí a postoje pedagogů ke vzdělávání ve venkovním prostředí pro žáky, kteří vyžadují speciálněpedagogický přístup.

\section{Výuka na školní zahradě}

\section{1 Žák se speciálními vzdělávacími potřebami}

Žákem se speciálními vzdělávacími potřebami (SVP) rozumíme žáka, který „k naplnění svých vzdělávacích možností nebo k uplatnění nebo užívání svých práv na rovnoprávném základě s ostatními potřebuje poskytnutí podpůrných opatření. Podpůrnými opatřeními se rozumí nezbytné úpravy ve vzdělávání a školských službách odpovídající zdravotnímu stavu, kulturnímu prostředí nebo jiným životním podmínkám žáka." (Zákon č. 561/2004 Sb., §16, odst. 1). Někteří žáci se SVP mají vytvořený individuální vzdělávací plán (IVP), který reflektuje jejich zdravotní limity a potřeby. Na tvorbě individuálního vzdělávacího plánu spolupracuje multidisciplinární tým - školní psycholog, výchovný poradce, školní metodik prevence, speciální pedagog, třídní učitel, rodiče, žák (Vyhl. č. 27/2016 Sb.).

Žák se SVP může mít různá znevýhodnění: sociální (etnicita, poruchy chování) nebo zdravotní (fyzické nebo duševní). K jeho znevýhodnění by se mělo přistupovat individuálně a empaticky, jeho zdravotní stav by měl být zohledněn v bio-psycho-sociální rovině. Žák se SVP vede kvůli svému znevýhodnění jiný životní styl než ostatní (Hájková \& Strnadová, 2010). Úkolem výzkumníka je odhalovat limity a specifika žákova zdravotního stavu, která se projevují při různých aktivitách odlišně. Když budou odhalovány limity žáka se SVP, bude možné lépe podporovat a rozvíjet pedagogy, kteří s takovými žáky pracují. 


\subsection{Výuka na školní zahradě}

Využívání školních zahrad pro výuku na základních školách má v našich podmínkách velmi dlouhou tradici. Úsilí škol systematicky prohlubovat pozitivní vztah žáků k přírodě můžeme odvozovat již od myšlenek J. A. Komenského, který tento požadavek vtělil do řady svých pedagogických textů. Můžeme zmínit např́klad jeho zásadu názornosti a systematičnosti - přírodu a př́írodní děje lze v souladu s touto zásadou velmi dobře didakticky využít (Morkes, 2010). Přestože původně školní zahrady měly sloužit zejména pro učitele, kteří si část obživy měli vypěstovat, staly se místem, kde probíhala zejména praktická výuka v oblasti zemědělství. Učitelé začali školní zahrady přirozeně začleňovat do výuky, a předávali jejich prostřednictvím žákům znalosti z oblasti pěstitelství, sadařství nebo včelařství. Školní zahrady se tak postupem času staly neodmyslitelnou a žádoucí součástí edukačního procesu na úrovni základního vzdělávání. „Za první programově a již koncepčně založenou ,školní zahradu' je možno považovat zahradu vybudovanou v tzv. Budči v Praze ve 40. letech 19. století. Iniciátorem a zřizovatelem Budče jako moderně a značně ambiciózně budovaného vzdělávacího zařízení byl MUDr. Karel Slavoj Amerling (1807-1884)." (Morkes, 2010). Velkým krokem k zakotvení pozice školních zahrad byl pak říšský školský zákon z roku 1869, podle něhož měly při venkovských školách vznikat školní zahrady a pozemky. Po roce 1918 byla školní zahrada právoplatnou součástí školy a žáci na ní měli být zaměstnáváni jak individuálně, tak při skupinové práci. Snahou bylo zřizovat školní zahrady i při městských školách. Práce na školní zahradě měla být v souladu se školní výukou i ročním obdobím. Využívání školních zahrady před rokem 1989 směřovalo k tradičnímu využití, tedy zejména k výuce pěstitelských prací a tělesné výchovy. Po zavedení rámcového vzdělávacího programu (RVP) v roce 2004 se pěstitelské práce na pozemcích škol začaly vytrácet a došlo k přirozené proměně účelu provozování školních zahrad. V tomto období začal růst význam ekologické výchovy.

Velkou propagátorkou školních zahrad a jejich využití pro ekologickou výchovu a všechny vyučovací předměty byla Mgr. Květoslava Burešová, která stála u vzniku střediska Chaloupky u Třebíče, které v jejím odkazu propagace využívání školních zahrad a výuky v terénu pokračuje dodnes. Květoslava Burešová byla autorkou celé řady publikací, které se věnovaly námětům a návodům na realizaci témat z oblasti ekologické výchovy. Nejvýznamnější publikací shrnující její celoživotní snažení a směřování je manuál pro školní zahrady Učíme se v zahradě, který vyšel v roce 2007. Její výzkum, započatý 
v roce 2004, měl za cíl zjistit stav školních zahrad při základních školách v České republice. Do výzkumu bylo zapojeno 486 škol z celé České republiky. Bylo zjištěno, že 80,5 \% dotázaných škol vlastní školní zahradu, většina zahrad byla v rámci areálu školy a celých 97 \% škol, které zahradu mají, ji využívá k výuce alespoň jednoho předmětu; většina škol využívá školní zahradu pro aktivity družiny a pro relaxaci během přestávek (Burešová, 2007). Podobným výzkumem se zabýval Vácha (2015), který zkoumal využití školních zahrad na prvním stupni základních škol.

Dnes můžeme hovořit o renesanci školních zahrad, které se stávají aktivním edukačním prostředím. Školní zahrady dnes mohou sloužit k výuce celé řady předmětů, a to nejen těch, které by se vzhledem k tradici nabízejí. Na zahradách vznikají bylinkové záhony, geoparky, stezky bosých nohou, koutky s hudebními nástroji a také různé formy zázemí, které umožňují výuku téměř kteréhokoli předmětu bez ohledu na počasí. Školní zahrady se tak stávají př́írodními učebnami. Přírodní učebnou rozumíme jakýkoli prostor v blízkém okolí školy, kde se žáci mohou učit nejrůznější předměty pod širým nebem v interakci s okolní přírodou (Křivánková, 2015).

Využívání školních zahrad představuje sílící trend i v zahraniční, v anglicky psané literatuře můžeme najít pojem garden-based education, v německém prostředí pak Gartenpädagogik. V zahraničí je využívání školních zahrad často spojeno se zahradničením, při kterém žáci pracují na školní zahradě a pěstují vlastní zeleninu a ovoce, které jsou dále zužitkovány ve školní kuchyni. Cílem je nejen předávat znalosti, ale také budovat zdravé stravovací návyky. Tento trend reaguje na vysoký výskyt dětské obezity ve vyspělých zemích, který může vést k rozvoji dalších chronických neinfekčních onemocnění, jako je např́íklad diabetes mellitus (Leuven et al., 2018). Pobyt ve venkovním prostředí má celou řadu zdravotních efektů, např́iklad snížení krevního tlaku, zvýšení produkce vitamínu D pozitivně ovlivňujícího fungování imunitního systému a v neposlední řadě také posílení duševního zdraví. Práce a pobyt na zahradě kombinují fyzickou aktivitu (obnovení síly a obratnosti) se sociální interakcí a expozicí slunečnímu záření (Thompson, 2018).

Školní zahrada je místem, kde lze získávat a upevňovat nové vědomosti, postoje i kompetence, které jsou důležité pro další život jedince. Tyto aspekty byly podrobeny zkoumání v rámci výzkumu realizovaného $\mathrm{v}$ Texasu, kde se žáci základní školy zapojili do jednoletého výukového programu realizovaného na školní zahradě. Tento výzkum sledoval šest dovedností, které jsou 
velmi důležité pro to, aby z dětí vyrostli sociálně odpovědní a úspěšní občané. Byly hodnoceny následující dovednosti: práce v týmu, sebeporozumění, schopnost vést skupinu, schopnost rozhodovat se, komunikativní dovednosti, dobrovolnictví. Výzkum zjistil pozitivní vliv výuky na školní zahradě ve schopnosti vést skupinu a v sebeporozumění (Robinson \& Zajicek, 2005).

Výuka vedená ve venkovním prostředí poskytuje prostor pro pozorování, experimentování, objevování, posilování sebedůvěry, rozvoj motorických dovedností apod. Díky výuce vedené na školní zahradě se žáci učí rozumět přírodě, ekosystémům, chápat jejich zákonitosti, rytmičnost a důsledky antropogenní činnosti. Pomáhá tak znovu nalézt úctu k půdě i manuální činnosti a také přijímat zodpovědnost za vlastní zdraví prostřednictvím výběru vhodných potravin (Blair, 2010).

Žáci s SVP vyžadují speciálněpedagogický přístup, který umožní maximální rozvoj jejich potenciálu. Výuka vedená na školní zahradě tak může být na první pohled daleko náročnější, nebot' žáci mají oslabené určité mentální či tělesné schopnosti. Na druhou stranu je pobyt venku př́ležitostí, jak plně využít multisenzorické učení v reálném čase, zlepšit motorické a koordinační dovednosti a posilovat sociální interakce (Hussein, 2010).

Některé školy se snažily pokročit ve svém počínání ještě o kousek dál a jejich zahrada se stala certifikovanou př́rodní zahradou. Na takové zahradě se hospodaří bez rašeliny, bez umělých hnojiv, bez pesticidů. Projekt přírodních zahrad je iniciativou spolkové země Dolní Rakousko a na našem území je tento projekt rozvíjen již od roku 2001. V roce 2020 bylo takových zahrad 103 a mezi nimi byly i zahrady školní (Přírodní zahrada, 2018).

Školní zahrada je multifunkčním a aktivizujícím prostorem, který má široké uplatnění v oblasti školní i mimoškolní edukace. Zcela nový rozměr do diskuzí o využívání školních zahrad přinesla v roce 2020 epidemie covid-19, nebot' výuka ve venkovních prostorách je z epidemiologického hlediska podstatně méně riziková nežli výuka ve školních učebnách. Nejde samozřejmě jen o omezení přenosu viru, ale také o to, že pobyt venku za dodržení určitých podmínek posiluje obranyschopnost dětí i dospělých.

\subsection{Teoretická východiska}

Vzhledem k interdisciplinární povaze zkoumané problematiky je tato studie založena na několika rozdílných, avšak vzájemně kompatibilních teoretických 
konceptech. Hlavním teoretickým rámcem studie je sociální pedagogika v širokém pojetí, tedy věda o roli prostředí ve výchově (Kraus \& Poláčková et al., 2001). Knotová (2004) ř́ká, že zejména pozvolna sílící antropologické paradigma takto široce pojaté sociální pedagogiky odráží přístupy, které jsou v tomto textu uplatněny: orientace na člověka a jeho aktivní roli při interakci $\mathrm{s}$ výchovným prostředím, důraz na systemický přístup k člověku i prostředí apod. Teoretické uchopení vztahu člověka a př́rody s akcentem na zodpovědnost člověka za další vývoj globálních problémů řeší další z východisek studie, environmentální etika (Des Jardins, 2013). Tento přístup, kromě jiného, předpokládá redefinici vztahu člověka k přírodě, která mj. spočívá v překonání tradičního dualismu „člověk vs. příroda“. Předpokladem k tomu je právě autentický zážitek vychovávaného jedince, který může škola ve specifickém edukačním prostředí zprostředkovat, a navíc následně navodit jeho žádoucí reflexi. Dalšími teoretickými a teoreticko-praktickými koncepty, které se v intencích výše uvedených východisek v našem přístupu uplatňují jsou např. komunitní vzdělávání a zážitková pedagogika.

\subsection{Cíle a metodologie výzkumu}

Cíle výzkumu jsou stanoveny nejen v oblasti teoretické, ale i praktické. Na základě analýzy dokumentů, rozhovorů a pozorování budou vymezeny slabé a silné stránky využívání školní zahrady s cílem navrhnout a vytvořit inovativní metodiku pro komplexní využívání širokého edukačního potenciálu školní zahrady vzhledem ke specifickému složení žáků této školy. Tuto metodiku bude možné inspirativně využívat i na dalších školách podobného zaměření. $V$ současné chvíli výzkum stále probíhá, a proto je možné publikovat jen dílčí závěry. V oblasti praktické je cílem navrhnout inovace vybavení a pomůcek na školní zahradě tak, aby bylo možno školní zahradu efektivně využívat pro edukaci žáků se specifickými vzdělávacími potřebami.

V předkládaném výzkumu byl využit kvalitativní přístup. Jednalo se o akční výzkum s designem prŕpadové studie. Výzkum se opírá především o pozorování a o polostrukturované rozhovory s vedením školy, učiteli, koordinátorem EVVO (Environmentální vzdělávání, výchova a osvěta), výchovným poradcem, školním metodikem prevence a se žáky školy. V dubnu 2017 probíhala první fáze pozorování žáků při výuce na školní zahradě, na jehož základě se podařilo vyhledat učitele, kteří byli následovně osloveni s žádostí o rozhovor. V další fázi byly studovány kurikulární dokumenty školy, jednalo se o školní vzdělávací program (ŠVP) a program EVVO, který je součástí koncepce 
školy. Další pozorování žáků a učitelů proběhlo během měsíce května 2019, kdy se škola účastnila akce Měsíc školních zahrad, každoročně vyhlašované Mezinárodní asociací školních hřišt' a zahrad (ISGA). V tomto měsíci se na školní zahradě obvykle vystř́ídá větší část tříd školy, a je tak možné vybrat třídu pro dlouhodobější pozorování. Pozorování mělo původně proběhnout již během školního roku 2019/2020, ale situace během epidemie a následné uzavření škol neumožňovaly plán pozorování realizovat. Oslovení třídní učitelky se souhlasem vedení školy se povedlo během srpna 2020. Podrobnosti pozorování a souhlas rodičů s probíhajícím výzkumem na školní zahradě byly zajištěny během září 2020. Před zahájením výzkumu byla prostudována školní dokumentace jednotlivých žáků. Pozorování je nezúčastněné, začíná již během přesunu na školní zahradu a končí návratem do třídy. Jednotlivé aspekty pozorování jsou zaznamenány do připravených pozorovacích archů.

Pozorovací archy zahrnovaly informace o venkovní teplotě, seznam př́tomných žáků, činnost žáků během výuky, a především sledované aspekty. Při pobytu na školní zahradě bylo pozorováno, jak jsou žáci schopni se adaptovat na klimatický diskomfort, jaké emoční reakce doprovázejí pobyt venku, zda projevují zájem o objekty a děje v zahradě, jestli se aktivně zapojují do připravených činností a jak kooperují s ostatními žáky. Dále bylo zaznamenáváno, zda se v průběhu pobytu venku vyskytly problémy, které by mohly mít z pohledu žáků negativní vliv na průběh výuky na školní zahradě. Po návratu do školy byly hodnoceny známky únavy.

Adaptace na klimatický diskomfort je rozdělena na tři složky. Kognitivní složka sleduje schopnost správně vyhodnotit oblečení odpovídající aktuálnímu počasí. Emoční složka zachycuje schopnost snášet nepohodu. Konativní složka zohledňuje schopnost samostatně se obléknout a manipulovat např́klad se zipem nebo tkaničkami. Velmi dobrá adaptace zahrnuje, že žák má obvykle vhodné oblečení vzhledem k počasí, a nepocituje proto diskomfort, obléká se samostatně. Dobrá adaptace znamená, že žák nemá vždy vhodné oblečení a je potřeba vhodné oblečení opakovaně připomínat a dopomáhat při oblékání. Špatná adaptace svědčí o neschopnosti vyhodnotit správné oblečení pro aktuální počasí a pozdější pocit'ovaný teplotní diskomfort během pobytu na zahradě. Při oblékání musí výrazně pomáhat asistentka pedagoga.

Známky únavy po návratu do budovy sledují míru únavy a útlumu aktivity. Velmi výrazné známky zahrnují velký útlum aktivity, který může směřovat k nutnosti odpočívat v relaxační části třídy. Výrazné známky zahrnují útlum 
aktivity, který po krátké pauze a svačině již nepřetrvává. Nevýrazné známky zahrnují stav, kdy nejsou pozorovány viditelné známky únavy.

Emoční reakce na pobyt venku zahrnuje projevovanou verbální i neverbální radost z pobytu venku. Velmi kladná reakce zahrnuje verbální i neverbální vyjádření kladných pocitů. Kladná reakce zahrnuje vyjádření spíše ve složce neverbálních projevů. Neutrální reakce popisuje velmi nízký nebo žádný projev emocí ve verbální i neverbální složce.

Projevy zájmu o objekty a děje v zahradě posuzují například zájem o přírodní děje, proměny př́rody během roku, změny počasí, pozorování živočichů a rostlin. Velmi výrazné projevy obsahují aktivní zájem ze strany žáka o dění v př́rodě na školní zahradě. Výrazný projev zahrnuje schopnost všímat si př́rodních dějů za pomoci učitele. Nevýrazný projev popisuje převládající nezájem o dění v př́ŕrodě.

Aktivní zapojení do činností hodnotí zájem o nabízené aktivity a schopnost se zapojit, která se samozřejmě také odvíjí od zdravotního stavu žáků. Při spontánním a soustavném zapojení do aktivit vykazuje žák radost z probíhajících činnosti a jeví o ně zájem trvalejšího charakteru. Při spontánním zapojení je potřeba vyšší motivace a podpory pro dokončení činnosti. Při řízeném zapojení je žák opakované směřován učitelem k zapojení se do činností.

Projevy kooperace sledují ochotu spolupracovat s ostatními žáky na zadaných úkolech v prostředí školní zahrady. Dobrá úroveň kooperace v sobě obsahuje zájem a ochotu spolupracovat se spolužáky. Mírná úroveň zahrnuje vyšší míru podpory ze strany učitele. Nízká úroveň kooperace popisuje chování, kdy žák raději volí práci o samotě a spolupráci opakovaně a cíleně nevyhledává.

V kategorii problémů jsou sledovány možné komplikace (např. úraz či znečištění oděvu), které mohou negativně ovlivnit vnímání výuky na školní zahradě z pohledu žáků. Vysoká míra problémů zahrnuje komplikace při výuce, které vedou ke snížení zájmu o pobyt na školní zahradě. Mírné problémy značí, že žák nějaké problémy měl, ale dobře se s nimi vyrovnal. Žádné problémy značí, že žádné problémy nebyly u daného žáka pozorovány.

Aktivity pro výuku na školní zahradě připravuje třídní učitelka - vychází při tom ze školního vzdělávacího programu a respektuje mentální úroveň žáků. Při aktivitách je využíván prostor a vybavení školní zahrady (školní záhony, zahradnické nářadí, výukové pomůcky, kameny). Pobyt na zahradě je 
realizován pravidelně jednou týdně v rozsahu dvou vyučovacích hodin, předměty se prolínají. V zásadě však obsahují část českého jazyka, matematiky a př́rodovědy. V plánu je dále pozorování třídy po výuce na školní zahradě a pro komparaci klasická výuka ve třídě. V přípravě jsou také rozhovory s vyučující a vybranými žáky. Připravovaný rozhovor musí respektovat mentální úroveň žáků.

Do výzkumu byla vybrána třída základní školy speciální. Klíčem pro výběr třídy byla ochota učitelů realizovat část výuky na školní zahradě. Třída, která byla do výzkumu vybrána, má sedm žáků, tř̌i dívky a čtyři chlapce. Tři žáci jsou ve třídě letos noví a třída zahrnuje 8 . až 10. ročník povinné školní docházky. Tři žáci navštěvují 8. ročník, jeden žák navštěvuje 9. ročník a tři žáci chodí do 10. ročníku. Žáci se pohybují v pásmu středně těžké mentální retardace; tři z nich se vzdělávají podle individuálních vzdělávacích plánů a na vysvědčení jsou všichni hodnoceni slovně. Třídní učitelka i asistentka pedagoga je s touto třídou třetím rokem. Třída se jeví jako nekonfliktní a panuje zde klidná atmosféra. Verbální komunikace mezi žáky je během vyučovacích hodin sporadická, ale přátelská. Žáci jsou zvyklí si vzájemně pomáhat dle svých možností. Jeden žák se venku pohybuje pomocí vozíku, který někteří žáci umí ovládat a často pomáhají při transportu na zahradu. Třída se jeví jako pasivní a třídní učitelka by ji ráda více aktivizovala ve využívání svých znalostí a dovedností, které žáci často neumí uplatnit. I při výuce na zahradě lze pozorovat, že žáci nejsou iniciativní a spíše se řídí pokyny vyučujících. Osobu pozorovatele přijali bezproblémově, někteří dokonce aktivně komunikují, zejména žák s poruchou autistického spektra.

\subsection{Výsledky}

Jak již bylo řečeno, výzkum v terénu stále probíhá, a tak lze předložit pouze dílčí výsledky. Z neformálních rozhovorů a diskuzí s učiteli vyplynul zájem o sdílení zkušeností, a to hlavně v předmětech, které nejsou se zahradou přímo spjaty. Co dále lze tedy konstatovat v této fázi je, že žáci neměli žádný problém s akceptací výuky na školní zahradě (viz tabulka 1). Řada žáků přijala pobyt na zahradě s radostí nebo neutrálně. Neobjevila se žádná negativní reakce či obava z pobytu na zahradě. Ani během zimních měsíců, kdy počasí vyžaduje přípravu a nízká teplota ztěžuje některé činnosti, nikdo nevyjádřil požadavek na výuku ve škole. Žáci si během přesunu aktivně pomáhali, zejména pokud šlo o žáka, který využívá vozík. Pobyt na zahradě probíhal v klidné atmosféře, někteří žáci projevovali zájem o změny v zahradě. Z kraje 
října byla př́ijemná příležitost očesat zbytek malin a později i jablek, ze kterých žáci ve cvičné kuchyni připravili štrůdl. Z epidemiologického hlediska je pozitivní možnost pohybu na čerstvém vzduchu, i když žáci školy zřízené podle § 16 zákona 561/2004 nemají povinnost nosit roušku. Převážná část žáků však ochranu dýchacích cest ve škole nosí, protože mají řadu zdravotních komplikací, které jsou v případě onemocnění covid-19 rizikovým faktorem. Z pozorování je jasné, že žáci dobře snášejí nižší teplotní komfort. Co se v rámci pozorování jeví jako problematické, je určitá emoční plochost těchto žáků, která má za následek nutnost velmi detailního pozorování chování žáků. Žáci jen málokdy spontánně mluví a vyjadřují své emoce. Dle informací třídní učitelky jsou žáci po př́íchodu ze zahrady značně unaveni a je potřeba zařadit odpočinkové činnosti. Pak následuje asi hodina zvýšené aktivity a pak následuje opět útlum. Míra únavy po návratu do školy bude podrobena dalšímu zkoumání.

Celkově lze zatím říci, že pobyt na školní zahradě přináší pozitiva v oblasti podpory zdraví, rozvoje sociálních kompetencí, propojení teoretické a praktické výuky. Už samotný pobyt žáků venku je velkým přínosem ve zdravotní oblasti. Žáci v pásmu stř̌edně těžké mentální retardace a s dalšími fyzickými i psychickými komplikacemi se často nemohou venku pohybovat zcela sami. Je tedy hlavně na jejich nejbližších, aby zajistili dostatečný pobyt venku, který zlepšuje imunitu, motorické dovednosti i samostatnost. Škola v této oblasti může přispět nejen hodinami tělesné výchovy, ale také právě pobytem na školní zahradě, která je pro tyto žáky relativně bezpečným, ale zároveň spontánním prostředím. Už v této fázi výzkumu je jasné, že by mělo dojít k částečné reorganizaci školní zahrady. Jde zejména o možnosti sezení, které jsou značně nevyhovující a neposkytují komfort pro tuto specifickou cílovou skupinu žáků. Dále by bylo vhodné nabídnout žákům koutek pro volnou a tvořivou hru, kde by byly k dispozici kulatiny, kameny a další materiál pro spontánní tvorbu. Ve spolupráci s vyučujícím pracovního vyučování bude zř́izena kamenná abeceda, krmítko a pítko pro ptáky. Potenciál školní zahrady je poměrně velký a je třeba pečlivě zvážit všechny možnosti, které se nabízejí. V následující tabulce je stručný souhrn dosavadních poznatků z pozorování žáků. 


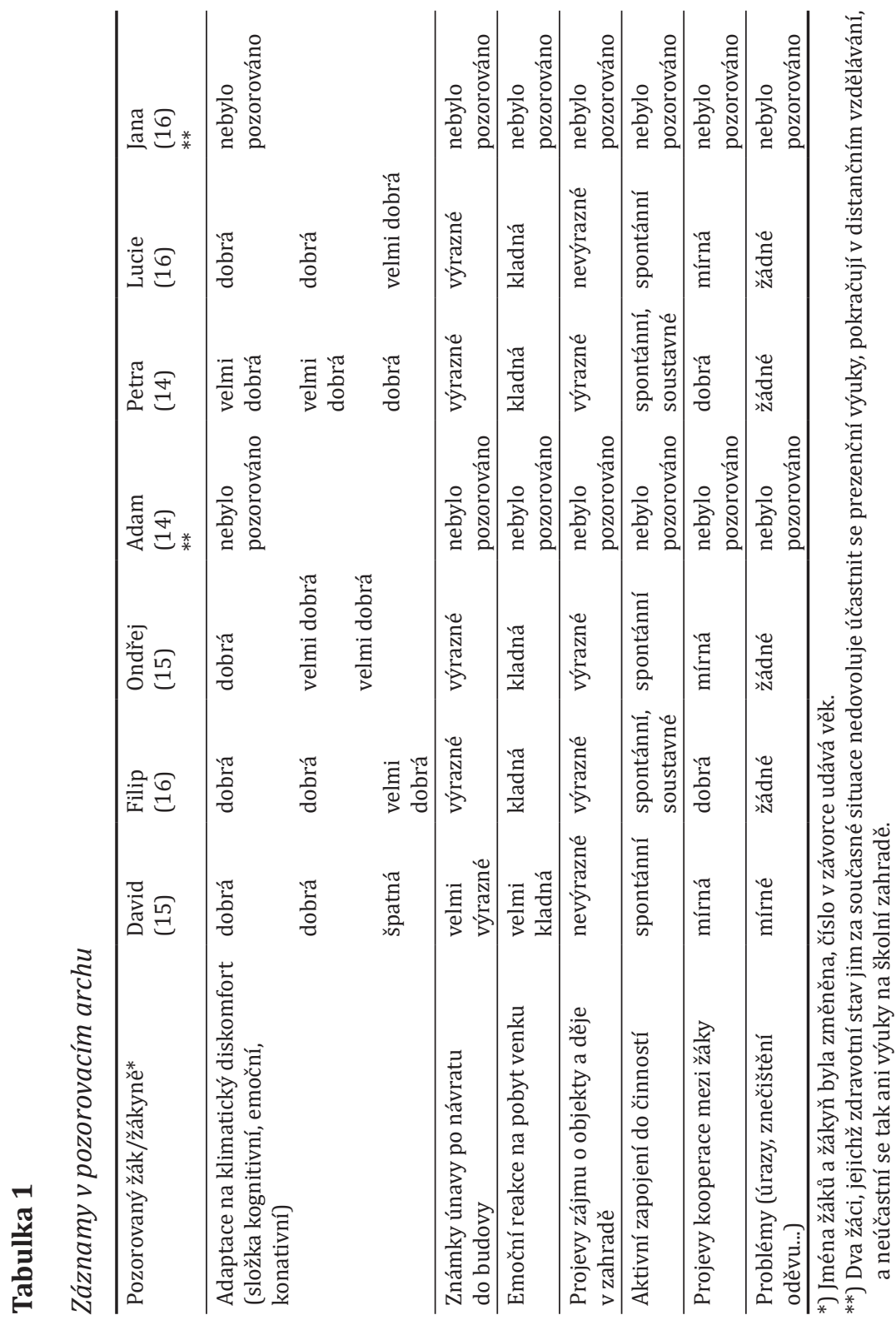




\section{Vzdělávání žáků s poruchou chování v lesním prostředí}

Cílem této části studie je popsat možnosti vzdělávání žáků s poruchou chování $\mathrm{v}$ lesním prostředí a postoje pedagogů z výchovných ústavů k takovému vzdělávání.

\section{1 Žák s poruchou chování}

V pedagogické praxi se můžeme setkat s problémovým chováním i poruchou chování (PCH). Obecně platí, že problémové chování, které není řešeno, může eskalovat do poruchy chování (Kaleja, 2014). Problémové chování může být jedním ze signálů vzniku pozdější poruchy chování. Samotné problémové chování není poruchou chování a ve vztahu k inkluzi nemá velký význam, protože do procesu inkluze jsou zařazeni žáci, kteří mají poruchu chování diagnostikovanou odborným školským poradenskými zařízením. V intervenční pedagogické praxi se problémy chování řeší běžnými přístupy, naopak PCH se řeší speciálními pedagogickými postupy v rámci IVP (Lechta, 2018).

Ve vědních disciplínách se na pojem PCH nahlíží z několika různých úhlů pohledů (lékařská věda, psychologie, speciální pedagogika). Klasifikace PCH je závislá na konkrétním vědním oboru. Pro hlubší vhled do problematiky rozlišujeme klasifikace:

- medicínské - MKN-10 - dg. F90-F98; DSM-IV - 5 os (čtvrtá verze maunálu DSM - Diagnostic and statistical manual of mental disorder);

- společenské - ukazatele normality dle Krause et. al (2001) - disociální, asociální, antisociální chování;

- dimenzionální - ASEBA, RBPC, CBCA;

- pedagogické/školské - neexistuje všeobecně zavedený systém - Seitzova klasifikace, Klugeho klasifikace, Rámcový profil (Váchová, 2016).

Diagnostickými kritérii (částečně dle DSM) pro určení PCH jsou například (Raboch et al., 2015): trvání déle než šest měsíců, příznaky neodpovídají aktuální vývojové úrovni, přítomnost znaků ve více prostředích.

PCH vychází ze spojitosti s chápáním pojmu porucha chování ve školním prostředí, kde se odráží v oblastech: konflikty, násilí, závislosti ke vztahu ke škole. Kategorizujeme je dle následujících jevů (Kaleja, 2013):

- výskyt agresivity (agresivní, neagresivní PCH); 
- prognóza (dobrá, špatná);

- vliv (PCH s vnitřními, vnějšími vlivy);

- míra socializace (socializovaná, nesocializovaná PCH);

- externalizované, internalizované PCH.

Dle dat OECD z roku 2009 je podpora žákưm s PCH poskytována v menší míře než žákům s SVP (Vojtová, 2010).

\subsection{Dilemata chápání PCH v pedagogické praxi}

Dilemata chápání PCH v pedagogické praxi vychází ze spojitosti s chápáním pojmu porucha chování ve školním prostředí, kde se odráží v oblastech: konflikty, násilí, závislosti ve vztahu ke škole.

Pedagogové nazírají na PCH každý z jiného úhlu pohledu. Mladší pedagogové označují za PCH převážně specifické PCH jako např. ADHD a nekladou takový důraz na sociální a výchovné vlivy. Starší pedagogové naopak uvádějí jako PCH nevychovanost, přemíru svobody, neúplnou rodinu, nepř́tomnost mužské autority v rodině (Jánský, 2016).

V případě volby přístupu k žákovi s PCH je důležité si uvědomit, s jakou PCH bude pedagog pracovat. Každá porucha chování vyžaduje individuální přístup (McLeskey et al., 2019). Nejčastěji to budou specifické PCH jako napřr. ADHD, dále PCH související se socio-kulturním prostředím žáka nebo v dnešní době diskutovaná tzv. dvojí výjimečnost. Dvojí výjimečnost je označení spojené se žáky disponujícími vysokým IQ a přidruženou poruchou učení, např. dysfunkční poruchou učení, kdy vzájemná korelace těchto dvou jevů vyústí v problémové chování a dále poruchu chování (Smítková, 2017). Tato skupina žáků je velmi těžko identifikovatelná, což může mít za následek rozvoj PCH. Dále se u těchto žáků můžeme setkat jen s mírnými projevy dysfunkčních poruch učení, protože vzhledem ke svému vyššímu intelektu zvládají přidružené poruchy alespoň částečně kompenzovat. To pak může vést k nepřijetí žáka do inkluzivního procesu, protože přidružené poruchy nejsou ještě natolik závažné, aby bylo nutné vytvoření IVP a použití podpůrných opatření (Dvořák et al., 2016).

Největší část žáků se SVP má diagnostikovanou specifickou poruchu chování - ADHD; podíl nespecifických PCH u žáků není přesně znám. Některé studie uvádějí podíl 16 až 20 \% žáků s PCH, ale procentuální vyjádření není 
zcela vypovídající, slučuje pojmy problémové chování a porucha chování do jednoho celku (Kaleja, 2013).

\section{Obrázek 1}

Dilemata chápání pojmu porucha chování

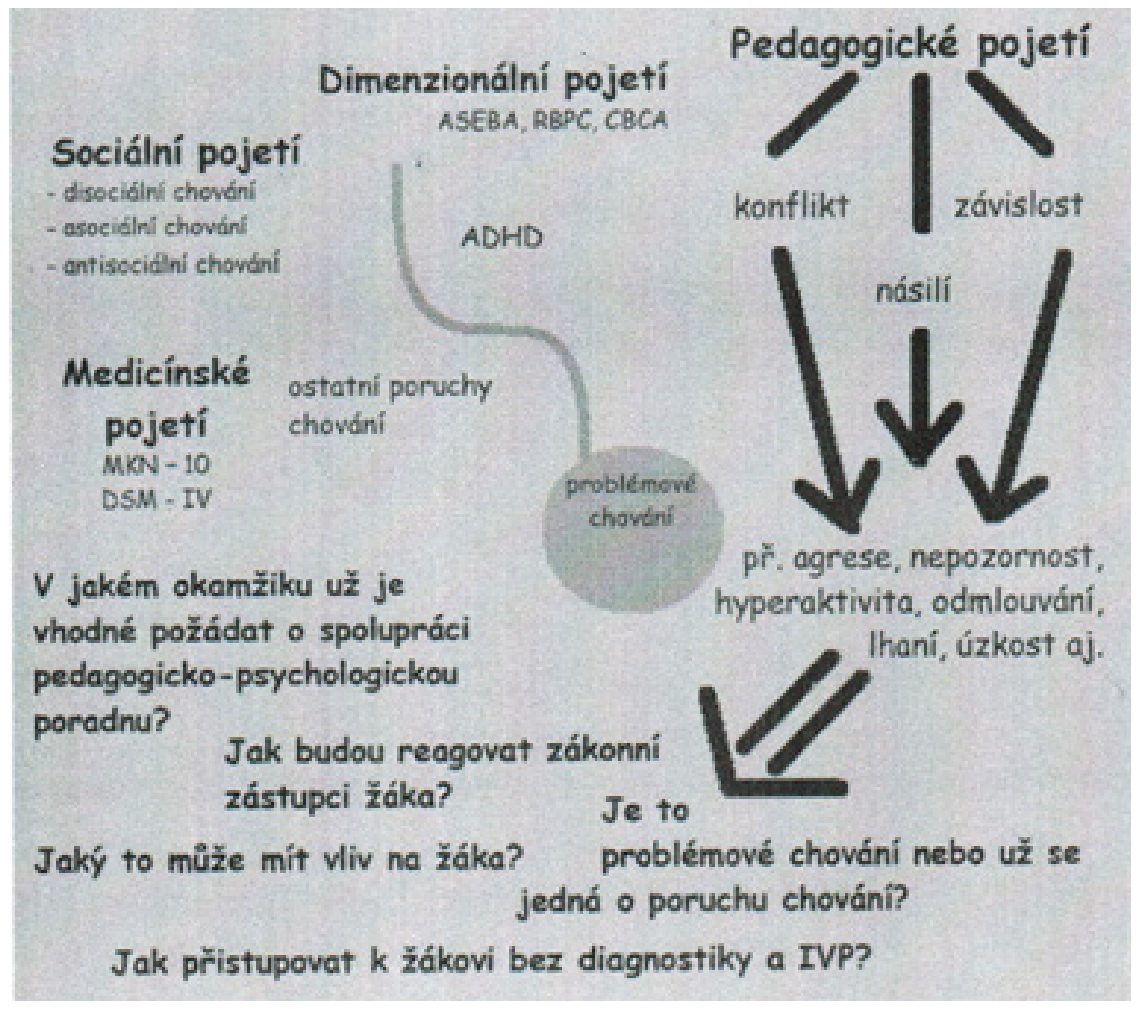

Zdroj: autoři.

Jánský (2016) uvádí, že se během výzkumu setkal u konkrétních žáků s odlišnými diagnózami různých odborníků stanovených $\mathrm{v}$ časovém horizontu několika měsíců po sobě. $Z$ toho plyne, že i odborníci se mohou ve svých závěrech diagnózy žáků s poruchou chování rozcházet. Pro pedagoga tak může být složité rozlišit hranici mezi problémovým chováním a PCH. Stránská 
(2017) na základě svého výzkumu uvádí, že pedagogové by se měli v oblasti vzdělávání žáků s PCH více vzdělávat, využívat vzdělávací kurzy nebo vzdělávání formou samostudia.

Při vzdělávání žáka s PCH je možné využít speciálních metod, jak ale přistupuje pedagog k žákovi, který nemá IVP a vykazuje problémové chování? Kdy je pravý čas požádat o pomoc pedagogicko-psychologickou poradnu? Při své práci může pedagog využít obecných postupů aplikovatelných na většinu žáků s různými PCH, jedná se o tři základní principy - stručnost, srozumitelnost a zpětnou vazbu. K celkovému pochopení ze strany žáka může pomoci dodržování dalších zásad: dosažitelnost cíle (přiměřenost, zainteresovanost, blízkost), sociální začlenění (akceptace, rovnováha, otevřenost), hodnocení (informace, individualizace, perspektiva; Vojtová, 2008).

\subsection{Vzdělávání v lesním prostředí}

Pozitiva vzdělávání v lesním prostředí lze spatřovat v oblasti ekologické, ekonomické a sociální. Častější kontakt s přírodou komplexním způsobem rozvíjí osobnost dítěte a jeho dovednosti. $V$ dřivějších dobách bylo těžké obhájit přínosnost výchovy v lesním prostředí pro mládež. Dnes už však existují výzkumy, díky kterým byl tento fakt prokázán a lze na něm stavět další tvrzení (Vošáhlíková, 2010).

Vošáhlíková (2010) dodává, že pobyt v přírodě má na děti pozitivní vliv v mnoha dalších ohledech. Jedná se například o zlepšení koncentrace a trpělivosti. Děti pobývající v prrírodě se učí lépe soustředit na právě prováděnou činnost a čekat na výsledky své práce ( $v$ prŕípadech, kdy v přírodě něco vytvářejí). Dále je u dětí rozvíjeno sociální chování, zejména kvưli nutným asociacím při činnostech venku a společných hrách. Děti se učí kooperaci, která je pro ně ve volném prostoru mnohem zábavnější než v izolovaném prostředí. Umění kooperace je pro život důležitou dovedností pro snazší začlenění se do společnosti nebo pro uplatnění se na trhu práce, kde je ve většině případů žádána schopnost práce $\mathrm{v}$ kolektivu. $\mathrm{V}$ neposlední řadě je vzdělávání $\mathrm{v}$ přírodě přínosné pro rozvoj dítěte také množstvím pohybu. Dochází k rozvoji obratnosti a vytrvalosti.

Klimánek a Kožíšek (1995) spatřují př́ínosnost pobytu v přírodě v chování, kterému se člověk $\mathrm{v}$ přírodě naučí. Jedinec musí, nebo by alespoň měl, v přírodě dodržovat jistý kodex a chovat se v souladu s ním. Woodcraft ř́íá, že pouze tiché chování umožňuje plné vychutnání si atmosféry lesa a splynutí s prrírodou. 
Novodobá mládež se k př́rodě chová mnohdy neuctivě, zejména když pohazuje po lesích odpadky nebo záměrně ničí porost a houby rostoucí v lese. Praktické zkušenosti ukazují, že dětí ovládají orientaci v terénu jen s velkými obtížemi. Myšlenku orientace $\mathrm{v}$ přírodě a vủbec využití veškerých dostupných využitelných zdrojů, které příroda nabízí, opět učí woodcraft (Řandová, 2016).

Německý sociolog Häfner se věnoval otázce, zda koncepce výchovy, resp. převýchovy v lesním prostředí nemůže mít na vychovávaného opačný efekt. V mnoha rodinách, zvláště pak v těch sociálně slabších, totiž chybí kontakt s prŕírodou. Není jasné, zda dítě umístěné na převýchovu do lesního prostředí neutrpí šok a na jeho chování to nebude mít negativní vliv. Autor pomocí dotazníků porovnával dovednosti dětí z lesních školek a dětí z běžných mateřských škol. Jejich schopnosti vyhodnocoval v šesti různých oblastech: koncentrace a trpělivost, sociální chování, spolupráce, hudební dovednosti, poznávací dovednosti a pohybové dovednosti. Ve všech kategoriích byly děti z lesních mateřských škol lepší, avšak nebylo bráno v potaz jejich socio-ekonomické prostředí (Vošáhlíková, 2010).

Díky různým činnostem, které je možno $\mathrm{v}$ přírodě vykonávat, se dítě naučí prosociálnímu chování. U žáků s poruchou chování je důležité zaměřit se na reedukaci v oblasti vlastních pocitů a vnímání, soustředění a trpělivosti a v neposlední řadě také kooperaci, bez které není jednoduché se v běžném životě obejít. Pokud budou všechny tyto schopnosti rozvíjený jako celek, šance na návrat do běžného společenského života se tím velmi zvyšuje.

Př́roda je zdrojem neutuchajících možností pro výchovu i sebevýchovu. Jde o speciální edukační prostředí, kde dochází nejen k rozvoji v sociální oblasti, ale i v oblasti psychologické. Samotný pobyt v př́rodě je jeden ze způsobů tzv. duševní hygieny. Člověk může v klidném prostředí odpočívat a zbavit sebe i svou mysl problémů každodenního života. Zároveň pobyt $\mathrm{v}$ př́rodě rozvíjí emocionální chápání. Skrz lesní moudrost a pravidla chování v lese dítě začne chápat své pocity, které do té doby neznalo nebo vůbec nemělo. Pobyt v lese děti nabádá ke změně chování; když se dítě bude řídit instinktivně a nebude se bránit změnám, povede pobyt v prrírodě jistě k úspěchům, díky kterým na sebe dítě může být hrdé. To vše také dětem pomáhá ve správném chápání své osoby ve společnosti, naučí se vážit si sebe samých. Emoce mají pro dítě nenahraditelný význam. Slouží jako motivační složka zvídavosti, pomáhají při vytváření a udržení sociálních vztahů, a tím pozitivně 
ovlivňují rozvoj veškerého poznávání. Základní emoce jako smích nebo pláč umí člověk používat již od narození. Některé další emoce, například vztek nebo láska, už jsou složitější a dítě se jim musí naučit. Jako vzor používá dítě svou matku, je tedy velmi důležité, jaký emoční vztah je mezi matkou a jejím dítětem. Pokud je vztah narušen nebo je vzor matky nevhodný, může dojít k osvojení chybného vzorce práce s emocemi a dítě se pak začleňuje do společnosti mnohem složitěji než jeho vrstevníci. Právě tento jev by pak mohl být alespoň částečně redukován pobytem $\mathrm{v}$ přírodě s odborným dozorem a péčí (Vágnerová, 2010).

Spasová (2007) prezentuje rozdíl mezi chováním dětí v uzavřeném a otevřeném prostoru. Ve své práci popisuje případ, kdy se chování skupiny chlapců, kteří se v běžné uzavřené tř́dě považovali za výjimečné a vždy museli každou hru vyhrát, změnilo během pobytu venku. Chlapci se chovali více prosociálně, dokonce se vraceli pro pomalejší spolužáky a pomáhali jim. Příčinou změny chování v závislosti na adaptaci na prostředí může být absence snahy být nejlepším nebo se před někým předvádět. $V$ přírodě je výhodnější spolupracovat než být sám, jedná se o jeden ze základních instinktů každého člověka. Ten pocitujuí i děti, jejichž socializační proces neprobíhal ideální formou.

Př́rodou probouzené základní instinkty nejsou ve městech nijak využívány. Např́iklad nucená spolupráce s ostatními z důvodu přežití není využita, a to i s jedinci, ke kterým člověk žádné sympatie nechová. Stejně tak se kvůli instinktům vytvoří přirozená struktura sociálních pozic. Venku se děti chovají jinak než ve škole a ti, kteří jindy působí statečně, se v přírodě mohou bát, případně naopak. To vede $\mathrm{k}$ přirozené diferenciaci a utvoření hierarchie, která je respektována, protože vznikla spontánně a na základě instinktů. Jednání podle vlastních instinktů navozuje taktéž pocit přirozené radosti.

\subsection{Teoretická východiska}

Jedním $\mathrm{z}$ významných myslitelů se vztahem $\mathrm{k}$ přírodě byl Jan Ámos Komenský. Zakladatel pedagogiky žijící v 17. století psal ve svých knihách o kladném vlivu přírodního prostředí na vývoj dětí. Myšlenky výchovy v přírodním prostředí jsou zmiňovány napříč všemi jeho díly, př́rodu zmiňuje např́íklad v díle Informatorium školy mateřské, ale i v pozdějších dílech, jako je například Obecná porada o nápravě věcí lidských. Dále stojí za zmínku Jean-Jacques Rousseau, filosof žijící v 18. století ve Francii, který se zabýval filosofií a pedagogikou a zamýšlel se, jak nejlépe vychovat svobodného 
člověka. Nepřímo tvrdil, že v prvních patnácti letech života dítěte je důležitá interakce $s$ prrírodou. Až poté navrhoval přemístit výchovu dítěte do města, kde se naučí přemýšlet o zázraku přírody. Henry David Thoreau se zabýval životem v lesním prostředí. Uchýlil se k životu v lese, aby dokázal co nejtransparentněji popsat své zážitky v prŕrodním prostředí. Dva roky žil v dřevěném srubu v lese a o svém pobytu později napsal knihu. $V$ životě v lesním prostředí a uvědomění, které z něj plyne, spatřoval Thoreau budoucnost mládeže. Velmi významnou osobností je E. T. Seton, zakladatel hnutí woodcraft a Ligy lesní moudrosti (Ǩandová, 2016).

Přírodovědec E. Westlake (vedoucí Řádu lesního rytířstva) tvrdil, že dítě v prenatálním vývoji prochází etapami vývoje od prvoka po člověka. Poznání, že obdobnými etapami prochází člověk i po svém narození a je neustále nucen učit se novým instinktům, jej přivedlo na myšlenku aplikovat stejné fáze učení na děti. Klíčový je výběr vhodného prostředí k určitým fázím, kterými si dítě musí projít. Potřebám zdárného tělesného a duševního vývoje nejlépe vyhovuje vesnický život, pobyt na svěžím vzduchu, chov domácích zvířat, táborové práce, výlety do okolí. Výchovným předpokladem woodcraftu je vlastní prožitek a zkušenost. Výchova v lesním rytířském řádu napomáhá nejen intelektuálnímu a fyzickému rozvoji, ale vede rovněž k jistému druhu rytířského chování. $\mathrm{V}$ kmenech, které $\mathrm{v}$ rámci řádu fungují, jsou děti podřízeny přirozené hierarchii vznikající na základě instinktů. Kritériem je např́klad věk, autorita apod. Přirozená diferenciace vede k rozvoji zdravého sebevědomí jedinců (Kolektiv autorů, 1995).

V Čechách se celý svůj život věnoval myšlence woodcraftu profesor Miloš Seifert, a je proto právem považován za zakladatele hnutí woodcraft v českých zemích. Seifert byl prvním, kdo zorganizoval letní tábor pro děti na způsob divokého indiánského kmene - a právě zde bylo postaveno první týpí v Česku a založen první kmen lesní moudrosti. První organizací, která se zabývala lesní moudrostí, byl Junák - český skaut založený v roce 1914 (Tichý, 2011).

\subsection{Výzkum}

Cílem studie bylo popsat vzdělávání žáků s poruchou chování v lesním prostředí a postoje pedagogů $\mathrm{z}$ výchovných ústavů $\mathrm{k}$ takové formě vzdělávání. Dále je stručně zmíněna zkušenost autorky se vzděláváním žáků s poruchou chování v lesním prostředí v Anglii (Řandová, 2016). Výsledky 
zde prezentované vychází z rozsáhlého výzkumného šetření realizovaného v roce 2015-2016. V rámci tehdejšího šetření byla pozornost zaměřena na přeměnu běžného výchovného ústavu ve výchovný ústav v lesním prostředí. Do hloubky byly zkoumány možnosti vzdělávání v lesním prostředí, legislativa nebo postoje pedagogů z výchovných ústavů ke vzdělávání v lesním prostředí.

Postoje pedagogů ke vzdělávání v lesním prostředí se mohou lišit, zjištovány byly postoje pouze u pedagogů z výchovných ústavů, protože ti pracují právě se žáky s poruchami chování. Šetření bylo realizováno kvalitativní formou výzkumu. Z oslovených výchovných ústavů se zúčastnily celkem čtyři, z nichž v každém byl realizovaný rozhovor v ohniskové skupině a poté individuální rozhovor s řediteli. Nástrojem byl polostrukturovaný rozhovor, který byl dle aktuální potřeby doplněn dalšími upřesňujícími otázkami na místě při rozhovoru. Data zjištěná na základě rozhovorů byla kódována a dekódována pomocí softwaru MaxQDA. Kódy byly rozděleny dle oblastí výzkumu. Následně byla provedena analýza formou „výkladu karet“, tedy popisu zjištěných skutečností. Dotazovaní pedagogové pocházeli z různých prostředí a různých výchovných ústavů, podat jednotnou charakteristiku zkoumaného vzorku nelze. Mezi rozdílné charakteristiky patří velikost města nebo obce, ve které je výchovný ústav umístěný, délka praxe a typy poruch chování, se kterými se setkávají. Mezi společné charakteristiky patří působení ve výchovném ústavu, př́má pedagogická činnost se žáky s poruchami chování, zkušenost s výukou v př́rodě. Výzkumného šetření se zúčastnilo celkem 31 pedagogů z toho 15 žen a 16 mužů.

\subsection{Výsledky}

Závěry získané na základě výzkumu jsou záměrně v této kapitole uvedeny v opačném pořadí než prve, jelikož zjištění získaná prostřednictvím rozhovorů s pedagogy se prolínají i do možností vzdělávání žáků s poruchou chování v lesním prostředí. Nejprve jsou tedy uvedeny výsledky týkající se postojů pedagogů ke vzdělávání v lesním prostředí, poté jsou uvedeny možnosti vzdělávání žáků s poruchou chování v lesním prostředí v ČR. 


\section{Postoje pedagogů ke vzdělávání v lesním prostředí}

Pedagogové byli dotazování na dvě konkrétní otázky:

1) Jaké výhody a nevýhody ve vzdělávání v lesním prostředí spatřují v souvislosti s psychologickým rozvojem žáků?

2) Jaké reakce lze očekávat od pedagogicko-psychologických poraden, rodičů, žáků samotných?

V odpovědích na první otázku týkající se psychologických dopadů na osobnost žáka se pedagogové téměř shodli. Jako výhody vzdělávání v lese vidí klidnější a podnětnější prostředí, více možností pro osobní projev žáků, absenci okolních negativních pokušení (návykové látky apod.) nebo možnosti dalšího rozvoje u žáků (motorické schopnosti, trpělivost, kooperace, respektování, chápání sebe sama). Jako nevýhodu vnímají téměř všichni pedagogové izolaci od společnosti, jejímž následkem může dojít k neosvojení si potřebných norem a návyků chování ve společnosti. Menší část pedagogů zmínila i přístup k technologiím, žáci by mohli být v tomto ohledu oproti vrstevníkům opožděni. Na druhou otázku odpověděli pedagogové podobně, a to tak, že reakce třetích stran by byly negativní. Po hlubším zkoumání vyšlo najevo, že pedagogicko-psychologické poradny by mohly mít námitky vzhledem k inkluzi, protože vzdělávání v lesním prostředí žáky izoluje, nikoli začleňuje. Dále by bylo třeba získat souhlas s pobytem venku od zákonných zástupců, což může být komplikované, a nakonec i souhlas žáků, protože pracovní a ergoterapeutické činnosti musí vykonávat dobrovolně, což se jim často nechce. Zhruba polovina dotazovaných pedagogů by činnost v přírodním prostředí ocenila.

Zajímavé byly taktéž úvahy pedagogů o dalších možnostech vzdělávání v lesním prostředí. Střediska výchovné péče mají možnost poskytnout žákovi tzv. internátní program, kdy je žák na základě dobrovolného rozhodnutí na časově omezenou dobu umístěn do prostředí, které je nejvhodnější vzhledem k jeho poruše chování a nabízí možnost resocializace a reedukace. Obdobné řešení by mohlo být realizováno prostřednictvím individuálního vzdělávacího plánu. Žák s poruchou chování by mohl mít nastavený IVP tak, aby trávil více času v lesním prostředí. Dále je vhodné zaměřit vzdělávací činnost více na praktické dovednosti a oblasti, o které jeví žák zvýšený zájem. 


\section{Možnosti vzdělávání v lesním prostředí}

V České republice zatím škola ani jiná vzdělávací instituce zaměřená na žáky s poruchou chování realizovaná v prostředí lesa není, ale legislativně možná je. Např́́klad v Anglii existuje výchovný ústav s vlastní školou zř́izený v lesní oboře nedaleko za městem. Jedná se o uzavřený areál, kde výuka probíhá v dřevěných srubech nebo přímo venku. Organizačně je výuka rozdělena na teoretické a praktické bloky. Během teoretických bloků se žáci učí vědomostem, během praktických bloků se věnují terapeutickým nebo pracovním činnostem, například staví dřevěné sruby, starají se o stromy, zvířata apod. Žáci jsou rozděleni do menších skupin a podle typu jejich poruchy, ve škole tráví stejný čas jako běžní žáci, ráno je rodiče do areálu dopraví a odpoledne opět vyzvednou. Legislativa by koncepci takové vzdělávací instituce v Čechách přímo nevylučovala, naopak s rozvojem lesních mateřských škol už jsou některé podmínky související se vzděláváním v přírodě legislativně vymezeny (Řandová, 2016).

Další z možností vzdělávání žáků s poruchou chování v lesním prostředí by mohl být přesun výuky př́mo do prostředí lesa. V současné době probíhá obdobný dočasný přesun výuky na základnách školách během tzv. škol v přírodě. Školy v přírodě jsou časově omezené a žáci se po jejich skončení vracejí zpět do běžného prostředí. Pokud by však škola byla umístěná př́mo v lesním prostředí, mohla by výuka probíhat i venku a se začleněním prvků, které jsou v běžném prostředí nedostupné.

\section{Závěr}

Závěrem lze shrnout několik zjištění, které z těchto dvou studií vyplývají. V předložených studiích, které se mohou zdát na první pohled odlišné, najdeme několik společných bodů. Obě studie se zabývaly žáky, kteří z různých důvodů vyžadují speciálněpedagogický přístup a kteří se ocitli během vzdělávacího procesu mimo tradiční školní třídu. Cílem bylo takové vzdělávání popsat a zhodnotit postoje pedagogů. Mezi společné výsledky obou studií můžeme zařadit dobré přijetí odlišného edukačního prostředí ze strany žáků, rozvoj jejich kompetencí využitelných v dalším životě i přirozenou hierarchizaci v rámci sociálního postavení ve skupině. Tato oblast zkoumání si jistě zaslouží další výzkumy, které by poskytly komplexnější pohled na danou problematiku. Tyto studie se tak mohou stát pomyslným odrazovým můstkem k dalšímu a podrobnějšímu zkoumání. 


\section{Literatura}

Blair, D. (2010). The child in the garden: An evaluative review of the benefits of school gardening. The Journal of Environmental Education, 40(2), 15-38.

Burešová, K. (2007). Učíme se v zahradě. Chaloupky, o.p.s.

Des Jardins, J. R. (2013). Environmental ethics. Cengage Learning.

Dvořák, D., Vyhnálek, J., \& Starý, K. (2016). Tranzice a transformace ve vzdělávací dráze: longituální studie rizikového žáka. Studia paedagogica, 21(3), 10-39.

Hájková, V., \& Strnadová, I. (2010). Inkluzivní vzdělávání. Grada.

Hussein, H. (2010). Using the sensory garden as a tool to enhance the educational development and social interaction of children with special needs. Support of Lerning, 25(1), 25-31.

Jánský, M. (2016). Poruchy chování jako sekundární symptom žáků s ADHD na 2. stupni základní školy (Disertační práce). Univerzita Karlova v Praze, PdF.

Kaleja, M. (2013). Ertopedická propedeutika v inkluzivní speciální pedagogice. Ostravská univerzita v Ostravě.

Kaleja, M. (2014). Determinanty edukace sociálně vyloučených žáků z pohledu speciální pedagogiky. Ostravská univerzita v Ostravě.

Knotová, D. (2004). Jaká je současná sociální pedagogika? In Konstituování sociální pedagogiky jako vědního oboru (s. 61-67). Institut mezioborových studií.

Kolektiv autorů. (1995). Kniha o woodcraftu (sborník článků a úvah kolektivu autorů o vzniku, významu a perspektivách woodcraftu - lesní moudrosti). Biblioteczka Walden.

Kraus, B., \& Poláčková, V. (eds.). (2001). Člověk - prostředí - výchova: K otázkám sociální pedagogiky. Brno: Paido.

Křivánková, D. (2012). Školní zahrada jako př́rodní učebna. Lipka.

Lechta, V. (2018). Inkluzivní vzdělávání. Portál.

Leuven, J., Rutenfrans, A., Dolfing, A., \& Leuven, R. (2018). School gardening increases knowledge of primary school children on edible plants and preference for vegetables. Food Science \& Nutrition, 6(7), 1960-1967.

McLeskey, J., Maheady, L., Billingsley, B., Brownell, M., \& Lewis, T. (Eds.). (2019). High leverage practices for inclusive classrooms. Taylor and Francis.

Morkes, F. (2010). Z historie školních zahrad. Envigogika, 5(2). https://www.envigogika.cuni.cz/ index.php/Envigogika/article/view/333/338

Př́rodní zahrada, z. s. (2018). Co je to prrírodní zahrada. http://prirodnizahrada.eu/co-je-toprirodni-zahrada-2/

Raboch, J., Hrdlička, M., Mohr, P., Pavlovský, P., \& Ptáček, R. (2015). DSM-5®: diagnostický a statistický manuál duševních poruch. Hogrefe - Testcentrum.

Robinson, C. W., \& Zajicek, J. M. (2005). Growing minds: The effects of a one-year school garden program on six constructs of life skills of elementary school children. HortTechnology, 15(3), 453-457.

Řandová, N. (2016). Postoje pracovníků výchovných ústavů k potencionální přeměně běžného výchovného ústavu ve výchovný ústav v lesním prostředí (Diplomová práce). Univerzita Hradec Králové, PdF.

Smítková, I. (2017). Psychologická identifikace dětí s dvojí výjimečností. Svět nadání: Časopis o nadání a nadaných, 7(2), 9-30. 
Spasová, S. (2007). Psychosociální klima ve školských zařizeních pro ústavní a ochrannou výchovu z hlediska sociální pedagogiky (Diplomová práce). Univerzita Karlova v Praze, PdF.

Stránská, A. (2017). Realizace podpůrných opatření u žáků se specifickými poruchami chování na běžných základních školách (Diplomová práce). Univerzita Karlova v Praze, PdF.

Thompson, R. (2018). Gardening for health: A regular dose of gardening. Clinical Medicine, 18(3), 201-205.

Tichý, F. (2011). Př́rodní škola - cesta jako cíl, aneb, Vyprávění o minulosti, současnosti a zkušenostech alternativního gymnázia. Geum.

Vágnerová, M. (2010). Psychologie osobnosti. Karolinum.

Vácha, Z. (2015). Didaktické využití školních zahrad v České republice na primárním stupni základní škol. Scientia in educatione, 6(1), 80-90.

Váchová, E. (2016). Metody intervence vedoucí $k$ začlenění dítěte v riziku poruch chování a s poruchami chování do kolektivu (Diplomová práce). Masarykova univerzita, PdF.

Vojtová, V. (2008). Úvod do etopedie. Texty k distančnímu vzdělávání. Paido.

Vojtová, V. (2010). Inkluzivní vzdělávání žáků v riziku a s poruchami chování jako perspektiva kvality života $v$ dospělosti. Masarykova univerzita.

Vošáhlíková, T. (2010). Ekoškolky a lesní mateřské školy: praktický manuál pro aktivní rodiče, pedagogy a zřizovatele mateřských škol. MŽP.

Vyhláška č. 27/2016 Sb.: Vyhláška o vzdělávání žáků se speciálními vzdělávacími potřebami a žáků nadaných (2016). http://www.nuv.cz/kipr/novela-vyhlasky-c-27-2016

Zákon č. 561/2004 Sb.: Zákon o předškolním, základním středním, vyšším odborném a jiném vzdělávání (školský zákon). (2004). http://www.zakonyprolidi.cz/cs/2004561

\title{
Autoři
}

Mgr. Bc. Nikola Adelaida Řandová, Univerzita Karlova, Pedagogická fakulta Ústav výzkumu a rozvoje vzdělávání, Myslíkova 7, 110 00,Praha 1, e-mail: niki.randova@gmail.com

PhDr. Alena Thorovská, Univerzita Karlova, Katedra pedagogiky, Pedagogická fakulta, Magdalény Rettigové 4, 116 39, Praha 1, e-mail: alena.thorovska@pedf.cuni.cz

\section{Environmental education of pupils with special needs}

\begin{abstract}
The issue of education and upbringing of pupils in the natural environment is a hot topic at present. Nature is a natural environment in which we have evolved over millions of years, and the need to stay in the natural environment is thus our evolutionary need. However, in today's technology-oriented world, contact with nature is disappearing very quickly. A number of studies reveal a declining rate of being outdoors. In connection with this, new terms are also emerging, such as "nature deficit disorder," used by the Richard Louv in his publication Last Child in the Woods. Thus, various educational and upbringing styles and other initiatives respond to the need for contact with nature, and it does not matter in which direction the children's relationship with nature will go and how the lack of living outside will affect their
\end{abstract}


health. The importance of being outdoors is confirmed by a number of studies, but is being outdoors beneficial to all children and pupils? How do pupils with special educational needs react to staying outside? The study is divided into 2 parts: education of pupils at a school garden and education of pupils with behavioural disorder in a forest. Both studies include interesting conclusions, for example no negative reactions of pupils to education in nature surroundings or that school professionals believe inclusive education and education in forest are complementary.

Keywords: education, pupils with special needs, nature, school garden, behaviour disorder 